\title{
主治医による死亡確認や臨終の立ち会いが, 家族の心理に及ぼす影響についての調査研究
}

\author{
新城 拓也 ${ }^{11}$, 森田 達也 ${ }^{2)}$, 平井 啓 ${ }^{3)}$, 宮下 光令 ${ }^{4)}$, \\ 佐藤 一樹 ${ }^{4}$, 恒藤 暁 ${ }^{5}$, 志真 泰夫 ${ }^{6)^{2}}$
}

\author{
1) 社会保険神戸中央病院 緩和ケア病棟, \\ 2) 聖隷三方原病院 緩和支持治療科, \\ 3) 大阪大学大学院 人間科学研究科医学系研究科, \\ 4) 東北大学大学院 医学系研究科保健学専攻緩和ケア看護学分野, \\ 5 ) 大阪大学大学院 医学研究科緩和医療学, \\ 6) 筑波メディカルセンター病院 緩和医療科
}

受付日 2010 年 5 月 12 日/改訂日 2010 年 8 月 6 日/受理日 2010 年 10 月 4 日

\begin{abstract}
本研究は, 主治医が終末期がん患者の死亡確認を行うことや臨終に立ち会うことが, 家族のつらさと医師の対応への改善の 必要性に影響するかを明らかにすることである. 2007 年, 95 のホスピス・緩和ケア病棟の遺族 670 名を対象に質問紙調 査を行った. 全体の $73 \%$ の遺族が回答した. どの医師が死亡確認を行うか, 医師が臨終に立ち会ったかは家族のつらさとは 関連がなかった. 一方, 死亡確認と立ち会いは, 医師の対応への改善の必要性とは有意な関連があった. しかし, 医師が「臨 終に立ち会ったこと」と,「立ち会えなかったが, その日は頻繁に部屋に来ていた」ことの間には, 医師の対応への改善の必 要度に有意差はなかった. したがって, 家族は主治医の死亡確認や, 臨終の立ち会いを望んでいるが, もし死亡確認や立ち会 いができなかったとしても, 心理的なつらさが強まることはなく, 臨終までに頻繁に部屋に行くことで十分な対応であると 考えていることが示唆された.

Palliat Care Res 2010; 5(2): 162-170
\end{abstract}

Key words: 終末期ケア, 死別, 死亡確認, がん

\section{緒 言}

終末期がん患者とその家族は, 身体的にも精神的にもケアの 必要性が高まる ${ }^{1,2)}$. 過去の研究で, がん患者や家族が望むこと は苦痛が適切に緩和されることと分かっている ${ }^{3-5)}$. 身体症状 の対処といった苦痛の緩和については, 多くの研究があるが, 患者や家族が望む医師や看護師の対応, コミュニケーションに ついては, 専門家の意見や経験的記述がほとんどで, 実際に患 者や家族の視点から実証された研究はほとんどない, ${ }^{1,2)}$. 特に, 継続的に診療に当たる医師が, その患者の死亡確認を行うこと と, 臨終に立ち会うことは家族の悲嘆にとって好ましい影響を 与えると経験的に考えられているが, 実際に死別を体験した家 族の評価を明らかにした研究はない。

本研究の目的は, 終末期がん患者の家族からみて, 主治医が 死亡確認を行うことや, 臨終に立ち会うことが, 家族の心理的 なつらさと医師や看護師の対応への改善の必要性に影響する かを明らかにすることである. 加えて, 看護師が臨終に立ち会 うことや, 心電図モニター使用が, 家族の心理的なつらさと医 師や看護師の対応についての, 改善の必要性に影響するかも検 討する.

\section{方 法}

\section{1 研究対象者}

本研究は,「遺族調査からみる臨終前後の家族の経験と望
ましいケア」の二次解析である ${ }^{6,7)}$.わが国のホスピス・緩和 ケア病棟で死別を体験した遺族を対象に行われた, 郵送によ る質問紙調査, The Japan Hospice and Palliative Care Evaluation (J-HOPE) Study の一部である ${ }^{8)}$.

適格条件は, わが国のホスピス・緩和ケア病棟で死別を体験 した遺族で, 患者の死亡時年齢が 20 歳以上, 遺族の年齢が, 患 者の死亡時に 20 歳以上とした. 遺族は, 患者の療養生活に最も 身近な遺族を 1 人選択した. 除外条件は, 遺族の住所が不明, 質 問紙に返答することが, 精神的に負担であると各施設の主治医 が判断した遺族とした。

本研究は, 95 のホスピス・緩和ケア病棟の 670 名の遺族を, 無作為に抽出した. 患者が, 2004 年 11 月から 2006 年 10 月ま でに死亡した遺族を対象とした. 質問紙は, 2007 年 6 月に遺族 に郵送され, 返答のない遺族に対しては, 再び 2007 年 8 月に郵 送した。

研究参加施設それぞれの倫理委員会で本研究の実施を検討, 承認後に調查を行った。

\section{2 質問紙}

本研究の質問紙は, 過去に臨終前後の患者のケア, 治療を検 証するうえで, 妥当性を確認された調査方法がないため, この 研究のために新たに作成した. 質問紙は, 主要調査項目として, 「臨終前後のできごとは, あなたにとってはどのくらいつらく 感じられましたか?」(1:「まったくつらくなかった」一5:「と てもつらかった」の 5 件法,つらさ)を設定した.さらに「臨 
終前後の医師や看護師の対応は, あなたからみてどの程度改 善が必要と感じられましたか?」(1:「改善の必要はない」一 4: 「改善の必要な点が非常にある」の 4 件法, 改善の必要性) を 過去の研究と同様に設定した ${ }^{9-12)}$.

次に, 医師や看護師の説明, 医師や看護師の行為, 患者の臨終 前後の状況, 臨終後の遺体の処置について質問を設定した ${ }^{6,7)}$.

さらに本研究のために, 臨終の状況として 1)「死亡確認を した医師は誰か」を,「主治医」「主治医以外だが, 知っている 医師」「主治医以外で, まったく知らない医師」の3つから，2) 「臨終の時, 主治医は立ち会っていたか」を,「部屋にいた」「部 屋にはいなかったが, その日は頻繁に部屋に来ていた」「部屋 にはいなかったし, その日はあまり部屋に来なかった」の3つ から, 3)「臨終の時, 看護師は立ち会っていたか」を,「部屋に いた」「部屋にはいなかったが, その日は頻繁に部屋に来てい た」「部屋にはいなかったし, その日はあまり部屋に来なかっ た」の 3 つから, そして, 4)「臨終前から心電図モニターをつ けていたか」を,「つけていなかった」「つけていた. 部屋にモ ニター装置はなかった」「つけていた. 部屋にモニター装置は あった」の 3 つから, それぞれ 1 つを選択するように 4 つの質 問を設定した.さらに, 遺族の年齢, 性別, 患者との関係, 患者の 死亡から調査までの期間を質問した。

各施設の主治医が, 患者の年齢, 性別, 原発部位, 患者の初診 から死亡までの期間を診療録から記録した。

\section{3 統計解析}

患者, 遺族の年齢は, 平均士標準偏差を求めた. 遺族の心理的 な「つらさ」と医師や看護師の対応への「改善の必要性」は, 度数と $95 \%$ 信頼区間 (confidence interval; CI) と共に頻度を求 めた.「つらさ」と「改善の必要性」はSpearmanの順位相関係 数で相関を検定した. 臨終の状況と, 遺族の「つらさ」と「改 善の必要性」を比較する目的に,「とてもつらい」(つらさの強 (群) とそれ以外, 「改善の必要性が非常にある, かなりある, 少しある」(改善の必要性が強い群) と「必要ない」の 2 群に 分類し,つらさの強い群と改善の必要性が強い群の頻度を求め た. 臨終の状況と,「つらさ」と「改善の必要性」の平均值で, 分散分析 (Kruskal-Wallis test) を行い, 統計学的に有意差があっ た群に対しては,さらに多重比較 (Steel Dwass 法) を行った. 検 定は, すべて $p<0.05$ を統計学的に有意とした.

統計解析には SPSS version 16.0 (SPSS, Chicago, IL), R version 2.11.0 (R Foundation for Statistical Computing, Vienna, Austria) 用いた。

\section{成 績}

質問紙が送付された 670 名のうち, 492 名 (73\%)の遺族が返 送した. 40 名は調査の参加を拒否, 18 名は主要調査項目の欠損 データのため除外, 残った 434 名 $(65 \%)$ を解析対象とした. 背 景因子は表 1 に示す.

「つらさ」と「改善の必要性」との間には, 弱い相関を認め た $(p=0.001, \rho=0.153)$. 臨終前後の体験は, とてもつらかった (45\%, 95\% CI, 41-50\%, n=197), つらかった $(29 \%, 95 \%$ CI, $24-33 \%, n=124)$, 少しつらかった $(18 \%, 95 \%$ CI, 15一 $22 \%, n$ =80), あまりつらくなかった $(6.5 \%, 95 \% \mathrm{CI}, 4.5-9.2 \%, \mathrm{n}=$ 28), まったくつらくなかった $(1.2 \%, 95 \% \mathrm{CI}, 0.5-2.7 \%, \mathrm{n}=5)$

\section{表 1 背景因子}

\begin{tabular}{|c|c|}
\hline & $\mathrm{n}(\%)$ \\
\hline 患者 合計 & 434 \\
\hline 年齢 (平均〔標準偏差〕) & $71(11)$ \\
\hline \multicolumn{2}{|l|}{ 性別 } \\
\hline 男 & $227(52)$ \\
\hline 女 & 207 (48) \\
\hline \multicolumn{2}{|l|}{ 原発部位 } \\
\hline 肺 & $118(27)$ \\
\hline 胃 & $52(12)$ \\
\hline 大腸, 直腸 & $51(12)$ \\
\hline 肝 & $26(6.0)$ \\
\hline 胆管, 膵臓 & $45(10)$ \\
\hline 食道 & $17(3.9)$ \\
\hline 乳腺 & $24(5.5)$ \\
\hline 前立腺, 腎, 膀胱 & $34(7.8)$ \\
\hline 頭頸部 & $12(2.8)$ \\
\hline 子宮, 卵巣 & $25(5.8)$ \\
\hline その他 & 30 (6.9) \\
\hline $\begin{array}{l}\text { 初診から死亡までの期間 } \\
\text { (平均〔標準偏差〕, 日) }\end{array}$ & $46(61)$ \\
\hline 遺族 合計 & 434 \\
\hline 年齢 (平均〔標準偏差〕) & 59 (13) \\
\hline \multicolumn{2}{|l|}{ 性別 } \\
\hline 男 & $150(35)$ \\
\hline 女 & $279(64)$ \\
\hline \multicolumn{2}{|l|}{ 患者との関係 } \\
\hline 配偶者 & $192(44)$ \\
\hline 子ども & $140(32)$ \\
\hline 嫁, 婿 & $44(10)$ \\
\hline 兄弟, 姉妹 & $31(7.1)$ \\
\hline その他 & $22(5.1)$ \\
\hline $\begin{array}{c}\text { 患者の死亡から調査までの期間 } \\
\text { (平均〔標準偏差〕, 月) }\end{array}$ & $12(4)$ \\
\hline
\end{tabular}

欠損データのため, 合計が 100\%にならない箇所がある.

の結果であった。

臨終前後の医師や看護師の対応一の, 「改善の必要性」につ いては, 非常にある $(1.2 \%, 95 \% \mathrm{CI}, 0.6$-3.0\%, n=6), かなりあ る (4.4\%, 95\% CI, 2.8一6.8\%, n=19), 少しある (37\%, 95\% CI, $32-41 \%, \mathrm{n}=159)$, 必要ない $(58 \%, 95 \%$ CI, $53-62 \%, \mathrm{n}=250)$ の結果であった.

患者の死亡確認を行った医師は, $61 \%$ が主治医であったと, 遺族は返答した. 死亡確認はどの医師かについては,つらさの 平均值と統計学的な有意差がなかったが $(p=0.52)$, 改善の必 要性の平均值には, 有意差を認めた $(p<0.001)$. 改善の必要性 が強い群の頻度は, 「主治医」「主治医以外だが, 知っている 医師」「主治医以外で, まったく知らない医師」は, それぞれ $33 \%, 57 \%, 60 \%$ であった. 改善の必要性の平均について,「主治 
表 2 遺族のつらさと, 医師や看護師の対応との関係

\begin{tabular}{|c|c|c|c|}
\hline & $\mathrm{n}(\%)$ & $\begin{array}{c}\text { つらさが強い頻度 } \\
\mathrm{n}(\%)^{*}\end{array}$ & $\begin{array}{c}\text { 改善の必要性が強い } \\
\text { 頻度 n }(\%)^{* *}\end{array}$ \\
\hline \multicolumn{4}{|l|}{ 1. 死亡確認 } \\
\hline 主治医 & $265(61)$ & $115(43)$ & $88(33)$ \\
\hline 主治医以外だが, 知っている医師 & $65(15)$ & $30(46)$ & $37(57)$ \\
\hline 主治医以外で, まったく知らない医師 & $86(20)$ & $41(48)$ & $52(60)$ \\
\hline \multicolumn{4}{|l|}{ 2. 臨終の時, 医師の立ち会い } \\
\hline 部屋にいた & $85(20)$ & $37(44)$ & $25(29)$ \\
\hline 部屋にはいなかったが, その日は頻繁に部屋に来ていた & $119(27)$ & $53(45)$ & $45(38)$ \\
\hline 部屋にはいなかったし, その日はあまり部屋に来なかった & $204(47)$ & $96(47)$ & $106(52)$ \\
\hline \multicolumn{4}{|l|}{ 3. 臨終の時, 看護師の立ち会い } \\
\hline 部屋にいた & $178(41)$ & $88(49)$ & $67(38)$ \\
\hline 部屋にはいなかったが, その日は頻繁に部屋に来ていた & $168(38)$ & $69(41)$ & $69(41)$ \\
\hline 部屋にはいなかったし, その日はあまり部屋に来なかった & $65(15)$ & $28(43)$ & $40(62)$ \\
\hline \multicolumn{4}{|l|}{ 4. 心電図モニター } \\
\hline つけていなかった & $318(73)$ & $142(45)$ & $142(45)$ \\
\hline つけていた. 部屋にモニター装置はなかった & $42(10)$ & $20(48)$ & $18(43)$ \\
\hline つけていた. 部屋にモニター装置はあった & $36(8.2)$ & $18(50)$ & $14(39)$ \\
\hline
\end{tabular}

欠損データのため, 合計が 100\%にならない箇所がある.

*臨終前後のできごとが,「とてもつらかった」群をつらさが強い群とした.

**臨終前後の医師や看護師の対応が,「改善の必要性が非常にある」「かなりある」「少しある」群の合計を改善の必要性が強い 群とした。

医」とそれ以外の群との間にそれぞれ統計学的な有意差を認 めた (表 2,3).

患者が臨終の時, 医師が「部屋にいた」と回答した遺族は 20\%であった. 医師が臨終に, 立ち会ったかについて,つらさの 平均值とは統計学的な有意差がなかったが $(p=0.53)$, 改善の 必要性の平均值には有意差を認めた $(p=0.001)$. また, 改善の 必要性が強い頻度は,「部屋にいた」「部屋にはいなかったが, その日は頻繁に部屋に来ていた」「部屋にはいなかったし, そ の日はあまり部屋に来なかった」群で,それぞれ $29 \%, 38 \%$, $52 \%$ であった. 改善の必要性の平均について,「部屋にはいな かったし, その日はあまり部屋に来なかった」群とそれ以外の 群との間にそれぞれ統計学的な有意差を認めた (表 2, 3).

患者が臨終の時, 看護師が「部屋にいた」と回答した遺族は 41\%であった. 看護師が臨終に, 立ち会ったかについて,つらさ の平均值には統計学的な有意差がなかったが $(p=0.32)$, 改善 の必要性の平均值には有意差を認めた $(p=0.001)$. また, 改善 の必要性が強い頻度は,「部屋にいた」「部屋にはいなかった が, その日は頻繁に部屋に来ていた」「部屋にはいなかったし, その日はあまり部屋に来なかった」群で, それぞれ 38\%, 41\%, $62 \%$ であった. 改善の必要性の平均について,「部屋にはいな かったし, その日はあまり部屋に来なかった」群とそれ以外の 群との間にそれぞれ統計学的な有意差を認めた (表 2, 3).

患者に心電図モニターをつけていなかったと返答した遺族 が, 73\%であった. 心電図モニターを「つけていなかった」「つ
けていた. 部屋にモニター装置はなかった」「つけていた. 部屋 にモニター装置はあった」群との間には,つらさの平均値とも $(p=0.93)$, 改善の必要性の平均值とも $(p=0.82)$ 統計学的な有 意差がなかった (表 2).

\section{考 察}

本研究では, どの医師が死亡確認を行うか, 臨終に, 医師や看 護師が立ち会うか, 心電図モニターをつけるかは, 臨終前後の 家族の心理的なつらさとは関連がなかった. 一方, 死亡確認が 主治医とそれ以外の医師, 臨終に, 医師や看護師が立ち会った かは, 医師や看護師の対応への, 改善の必要性には関連するこ とが分かった.また, 医師や看護師が「臨終に立ち会ったこと」 と,「立ち会えなかったが, その日は頻繁に部屋に来ていた」こ とは, 遺族の心理的なつらさにも, 対応の改善の必要度にも差 がないことも分かった.

この結果から, 家族は主治医による死亡確認や, 臨終に立ち 会いを望んでいるが，もし死亡確認や立ち会いができなくて も, そのために家族の心理的なつらさを強めることはないこと が示唆され, 主治医や看護師が臨終までに, 頻繁に部屋に行き, 患者の診察や家族の対応を行えば, 十分な対応であると家族は 考えていることが分かった。

臨終に医師が立ち会った経験のある遺族は, $20 \%$ と少数で あったが, 看護師が臨終に立ち会うことは $41 \%$ と医師よりも 
表 3 改善の必要性と, 医師や看護師の対応との比較

\begin{tabular}{|c|c|c|c|c|}
\hline & \begin{tabular}{|c|} 
改善の必要性 \\
(平均士標準偏差)*
\end{tabular} & グループ 1 & グループ 2 & $p^{* *}$ \\
\hline \multicolumn{5}{|l|}{ 1. 死亡確認 } \\
\hline 主治医 & $1.4 \pm 0.6$ & 主治医 & $\begin{array}{l}\text { 主治医以外だが, 知っている医 } \\
\text { 師 }\end{array}$ & 0.003 \\
\hline $\begin{array}{l}\text { 主治医以外だが, 知っている } \\
\text { 医師 }\end{array}$ & $1.6 \pm 0.6$ & 主治医 & $\begin{array}{l}\text { 主治医以外で, まったく知らな } \\
\text { い医師 }\end{array}$ & $<0.001$ \\
\hline $\begin{array}{l}\text { 主治医以外で, まったく知ら } \\
\text { ない医師 }\end{array}$ & $1.7 \pm 0.7$ & $\begin{array}{l}\text { 主治医以外だが, 知っている } \\
\text { 医師 }\end{array}$ & $\begin{array}{l}\text { 主治医以外で, まったく知らな } \\
\text { い医師 }\end{array}$ & 0.74 \\
\hline \multicolumn{5}{|l|}{ 2. 臨終の時, 医師の立ち会い } \\
\hline 部屋にいた & $1.4 \pm 0.7$ & 部屋にいた & $\begin{array}{c}\text { 部屋にはいなかったが, その日 } \\
\text { は頻繁に部屋に来ていた }\end{array}$ & 0.72 \\
\hline $\begin{array}{l}\text { 部屋にはいなかったが, その } \\
\text { 日は頻繁に部屋に来てい } \\
\text { た }\end{array}$ & $1.4 \pm 0.5$ & 部屋にいた & $\begin{array}{c}\text { 部屋にはいなかったし, その日 } \\
\text { はあまり部屋に来なかった }\end{array}$ & 0.004 \\
\hline $\begin{array}{l}\text { 部屋にはいなかったし, そ } \\
\text { の日はあまり部屋に来な } \\
\text { かった }\end{array}$ & $1.6 \pm 0.7$ & $\begin{array}{l}\text { 部屋にはいなかったが, その } \\
\text { 日は頻繁に部屋に来てい } \\
\text { た }\end{array}$ & $\begin{array}{c}\text { 部屋にはいなかったし, その日 } \\
\text { はあまり部屋に来なかった }\end{array}$ & 0.008 \\
\hline \multicolumn{5}{|l|}{ 3. 臨終の時, 看護師の立ち会い } \\
\hline 部屋にいた & $1.4 \pm 0.7$ & 部屋にいた & $\begin{array}{c}\text { 部屋にはいなかったが, その日 } \\
\text { は頻繁に部屋に来ていた }\end{array}$ & 0.85 \\
\hline $\begin{array}{l}\text { 部屋にはいなかったが, その } \\
\text { 日は頻繁に部屋に来てい } \\
\text { た }\end{array}$ & $1.5 \pm 0.6$ & 部屋にいた & $\begin{array}{c}\text { 部屋にはいなかったし, その日 } \\
\text { はあまり部屋に来なかった }\end{array}$ & 0.001 \\
\hline $\begin{array}{l}\text { 部屋にはいなかったし, そ } \\
\text { の日はあまり部屋に来な } \\
\text { かった }\end{array}$ & $1.8 \pm 0.8$ & $\begin{array}{l}\text { 部屋にはいなかったが, その } \\
\text { 日は頻繁に部屋に来てい } \\
\text { た }\end{array}$ & $\begin{array}{c}\text { 部屋にはいなかったし, その日 } \\
\text { はあまり部屋に来なかった }\end{array}$ & 0.004 \\
\hline
\end{tabular}

*改善の必要性; 1: 改善の必要はない一4: 改善が必要な点が非常にある

** Steel-Dwass 法による多重比較

高頻度であった.これは, ホスピス・緩和ケア病棟では少人数 で勤務する医師と, 24 時間勤務を交代しながら, 複数で対応 する看護師との勤務体制の違いを反映していると考えられる. 2009 年 5 月時点で, わが国には 195 のホスピス・緩和ケア病 棟が存在し ${ }^{13)}$, 本研究とあわせて行われた調査では, 調査に参 加した 100 のホスピス・緩和ケア病棟で, 平均 2 人の医師が 勤務しており, 夜間に緩和ケア病棟に勤務する医師が当直を 行っている施設は 3 施設のみで, また勤務時間外の電話での 呼び出しに対応する施設が 70 施設という調査結果であった ${ }^{8)}$. したがって, ほとんどの施設では, 少ない医師が勤務時間外も 含めて絶えず患者の対応している現状から, 医師が過労 (work overload) となる可能性が予想される.イギリスの調査で, 緩和 ケアに従事する医師のバーンアウト (燃え尽き) にも, 過労は 強く影響していることが報告されている ${ }^{14}$. 主治医の死亡確認 や, 臨終の立ち会いができなくても, 家族の心理的なつらさを 強めることはないという本研究の結果から, 過労によるバーン アウトを防ぐために, 勤務時間外の主治医の対応について, そ れぞれの施設で再検討してもよいかもしれない.

死亡確認はわが国では医師法で医師の業務として定められ
ており, 脳死判定を除けば慣習的に死亡の三徵候, すなわち 「呼吸の不可逆的停止」「心藏の不可逆的停止」「瞳孔散大 (対 光反射の消失)」で判定している ${ }^{15)}$.これらの死の定義は, 特定 の法律で定められたものではない ${ }^{15)}$. しかしながら慣習的にわ が国の病院では, 死亡確認の 1 つとして, 心電図の平坦化を確 認することも多い ${ }^{15)}$. 心電図の平坦化は死亡確認において, 必 須な条件ではないこと, また通常の死亡確認に特殊な検査は必 要ないという専門家の意見からも ${ }^{2)}$, 心電図モニターが必要で ある根拠はないと考えられる.さらに, 患者の臨終に立ち会い たいと考えている家族全員が揃ってから, 患者の死亡確認を行 うことが, 遺族は望ましいと考えていることが報告されてい る6). そして, 本研究の結果から死別を体験した家族が, 心電図 モニターの必要を重視していないことが分かった. したがっ て, 終末期がん患者の死亡確認に, 心電図モニターは不要で, さ らに患者の死亡を心電図の平坦化の瞬間とする必要はないと 考えられる.

本研究では, 臨終前後の体験が「とてもつらかった」「つら かった」と回答する遺族が, $74 \%$ と多数であるにも関わらず, 医師や看護師の対応についての, 改善の必要性が「非常にあ 
る」「かなりある」と回答する家族が, $5.6 \%$ と少数であった. さらに, 家族の心理的なつらさと, 医師や看護師の対応一の改 善の必要性とは相関が小さかった。これは, 家族にとって患者 との死別体験は本質的につらい体験であるが, ホスピス・緩和 ケア病棟で行われているケアや治療は基本的に適切であると 推測できる ${ }^{6}$.

本研究の限界として, リコールバイアスの関与が無視でき ない. 本研究では, 調査実施を患者の死亡から9-26力月 (平 均 12 力月) で行った. この期間より短ければ, 死亡直後の悲嘆 がより強く影響し，この期間よりも長ければ,よりリコールバ イアスが高まる. 過去の研究でも本研究とほぼ同じ期間を経て から調查を実施していることから,リコールバイアスの影響は 最小限であると推測される ${ }^{16,17)}$. 本研究では, 対象となる患者 はすべて, ホスピス・緩和ケア病棟で死亡しており, 専門的な 終末期ケアを受けている.よって, 本研究の結果が在宅, 介護施 設, 一般の病院といった他の施設でも一般化できるとは限らな い. さらに, 本研究のような横断的な調査方法では, 同定された 因果関係が当てはまらない可能性がある. また, 本研究で主要 調査項目として用いた,「つらさ」と「改善の必要性」は, 信頼 性や妥当性を検証された項目ではない. しかし,「つらさ」は調 査対象者にとって理解しや寸い項目であるし,「改善の必要性」 の項目は, 妥当性が確認されている先行研究の調査方法に同じ 質問が含まれているため ${ }^{9)}$, 本研究で得られた結果もまた十分 な妥当性があると考えられる.家族の心理的なつらさは多面的 で, 臨終前後で時間と共に変化していくと予想されるが, 本研 究では測定できなかった可能性がある. 死亡確認の方法や, 心 電図モニターの使用は, 医療者もしくは施設毎に方針が異なる 可能性がある.よって, 調査項目の関連要因に交絡している可 能性がある.さらに, 本研究では, 40 名の遺族が調査を拒否し た.これらの遺族は心理的なつらさが高かった可能性があり, 本研究の結果は過小評価された可能性がある.

最後に, 本研究の結果から, 終末期がん患者の家族は, 患者の 死亡確認や臨終の瞬間に立ち会うことよりも, 医師や看護師と の臨終までの関わりを重視しているとも考えられる.したがっ て,たとえ主治医や看護師は患者の臨終の瞬間に立ち会えなく ても, それまでの患者や家族との関わりが有意義であれば, 必 要以上に自責感を感じなくてもよいのかもしれない.さらに望 ましい臨終前後の医師, 看護師の対応と, 家族の体験する心理 的なつらさの因果関係を明らかにするために, 調査を拒否した 遺族も含めた質的研究が望まれる.

謝 辞 本研究は, 日本ホスピス・緩和ケア研究振興財団に よる,「遺族によるホスピス・緩和ケアの質の評価に関する研 究事業」として実施された.

\section{文 献}

1) Adam J. ABC of palliative care: The last 48 hours. BMJ 1997; 315: 1600-1603.

2) Hallenbeck J. Palliative care in the final days of life: "they were expecting it at any time.” JAMA 2005; 293: 2265-2271.

3) Heyland DK, Dodek P, Rocker G, et al. What matters most in end-of-life care: perceptions of seriously ill patients and their family members. CMAJ 2006; 174: 627-633.

4) Lynn J, Teno JM, Phillips RS, et al. Perceptions by family members of the dying experience of older and seriously ill patients: SUPPORT Investigators-Study to Understand Prognoses and Preferences for Outcomes and Risks of Treatments. Ann Intern Med 1997; 126: 97-106.

5) Redinbaugh EM, Baum A, DeMoss C, et al. Factors associated with the accuracy of family caregiver estimates of patient pain. $\mathrm{J}$ Pain Symptom Manage 2002; 23: 31-38.

6) Shinjo T, Morita T, Hirai K, et al. Care for imminently dying cancer patients: family members' experiences and recommendations. J Clin Oncol, 2010; 28: 142-148.

7) Shinjo T, Morita T, Miyashita M, et al. Care for the bodies of deceased cancer inpatients in Japanese palliative care units. J Palliat Med 2010; 13: 27-31.

8) Miyashita M, Morita T, Tsuneto S, et al. The Japan HOspice and Palliative Care Evaluation study (J-HOPE study): study design and characteristics of participating institutions. Am J Hosp Palliat Care 2008; 25: 223-232.

9) Morita T, Hirai K, Sakaguchi Y, et al. Measuring the quality of structure and process in end-of-life care from the bereaved family perspective. J Pain Symptom Manage 2004; 27: 492-501.

10) Morita T, Akechi T, Ikenaga $M$, et al. Communication about the ending of anticancer treatment and transition to palliative care. Ann Oncol 2004; 15: 1551-1557.

11) Morita $T$, Ikenaga M, Adachi I, et al. Family experience with palliative sedation therapy for terminally ill cancer patients. J Pain Symptom Manage 2004; 28: 557-565.

12) Morita $T$, Akechi $T$, Ikenaga $M$, et al. Terminal delirium: Recommendations from bereaved families' experiences. J Pain Symptom Manage 2007; 34: 579-589.

13) 日本ホスピス緩和ケア協会. 緩和ケア病棟入院料届出 受理施設に関する調査結果. [available at http://www.hpcj. org/what/pcu_list.pdf; accessed 11, Mar, 2010]

14) Graham J, Ramirez AJ, Cull A, et al. Job stress and satisfaction among palliative physicians. Palliat Med 1996; 10: 185-194.

15) 吉利 和. 診断学総論. 吉利 和, 鈴木秀郎, 宮下英夫, 他 編. 内科診断学, 改訂 7 版. 金芳堂, 京都, 1993; 14-16.

16) Morita $T$, Akechi $T$, Ikenaga $M$, et al. Terminal delirium: recommendations from bereaved families' experiences. J Pain Symptom Manage 2007; 34: 579-589.

17) Steinhauser KE, Christakis NA, Clipp EC, et al. Factors considered important at the end of life by patients, family, physicians, and other care providers. JAMA 2000; 284: 2476-2482. 


\title{
Who pronounced the patient's death? A study of the experience of bereaved Japanese families in palliative care units
}

\author{
Takuya Shinjo ${ }^{1)}$, Tatsuya Morita ${ }^{2)}$, Kei Hirai ${ }^{3)}$, Mitsunori Miyashita ${ }^{4)}$, \\ Kazuki Sato ${ }^{4)}$, Satoru Tsuneto ${ }^{5)}$, and Yasuo Shima ${ }^{6)}$
}

1) Palliative Care Unit, Shakaihoken Kobe Central Hospital,

2) Department of Palliative and Supportive Care, Palliative Care Team and Seirei Hospice, Seirei Mikatahara Hospital,

3) Center of the Study for Communication Design, Psychology and Behavioral Sciences, Graduate School of Human Sciences, \& Department of Complementary and Alternative Medicine, Graduate School of Medicine, Osaka University,

4) Department of Palliative Nursing, Health Sciences, Graduate School of Medicine, Tohoku University,

5) Department of Palliative Medicine, Graduate School of Medicine, Osaka University,

6) Department of Palliative Medicine, Tsukuba Medical Center Hospital

\begin{abstract}
Purpose: The aim of this study was to clarify the experience of the bereaved families at the time of death of a patient. Methods: A cross-sectional nationwide survey of the bereaved families of cancer patients was performed at 95 palliative care units in Japan in 2007. Results: Of the 670 questionnaires sent to bereaved families, 492 were returned (73\%). There were no significant differences between the level of the families' emotional distress and which doctor pronounced the death and whether the doctor was present at the moment of patients' death. Regarding the perceived need for improvement in the care of a dying patient, there were significant differences with respect to which doctor pronounced a patient's death and whether the doctor was present at the moment of a patient's death. There ware no significant differences between the attendance by doctor at the moment of patient's death and no attendance with frequent visit on that day. Conclusion: The bereaved families desire the patient's primary doctor to be present at the time of death and to then pronounce the death. However, the bereaved families consider an appropriate manner as the frequent visit by doctor on patient's last day even if the doctor do not attend at the moment of patient's death. Palliat Care Res 2010; 5(2): 162-170
\end{abstract}

Key words: end of life care, bereavement, death pronouncement, neoplasms 
Table 1. Demographic characteristics of the patients and their bereaved families

\begin{tabular}{|c|c|}
\hline & $\mathrm{n}(\%)$ \\
\hline Patients & 434 \\
\hline Age, Mean (SD) & $71(11)$ \\
\hline \multicolumn{2}{|l|}{ Sex } \\
\hline Male & $227(52)$ \\
\hline Female & $208(48)$ \\
\hline \multicolumn{2}{|l|}{ Primary tumor sites } \\
\hline Lung & $118(27)$ \\
\hline Stomach & $52(12)$ \\
\hline Colon, rectum & $51(12)$ \\
\hline Liver & $26(6.0)$ \\
\hline Bile duct, pancreas & $45(10)$ \\
\hline Esophagus & $17(3.9)$ \\
\hline Breast & $24(5.5)$ \\
\hline Prostate, kidney, bladder & $34(7.8)$ \\
\hline Head and neck & $12(2.8)$ \\
\hline Uterus, Ovary & $25(5.8)$ \\
\hline Others & $30(6.9)$ \\
\hline The period from first visit to death Mean (SD), days & $46(61)$ \\
\hline Bereaved families & 434 \\
\hline Age, Mean (SD) & $59(13)$ \\
\hline \multicolumn{2}{|l|}{ Sex } \\
\hline Male & $150(35)$ \\
\hline Female & $280(64)$ \\
\hline \multicolumn{2}{|l|}{ Relationship } \\
\hline Spouse & $192(44)$ \\
\hline Child & $141(32)$ \\
\hline In-laws & $44(10)$ \\
\hline Siblings & $31(7.1)$ \\
\hline Others & $22(5.1)$ \\
\hline The period from patient death to survey Mean (SD), months & $12(4)$ \\
\hline
\end{tabular}


Table2. Frequencies of high level of family-perceived emotional distress and the need for improvement in the care of a dying patient

\begin{tabular}{|c|c|c|c|}
\hline & $\mathrm{n}(\%)$ & $\begin{array}{c}\text { High level of } \\
\text { emotional distress } \\
n(\%)^{*}\end{array}$ & $\begin{array}{c}\text { High level of } \\
\text { necessity for } \\
\text { Improvement } \\
\mathrm{n}(\%)^{* *}\end{array}$ \\
\hline \multicolumn{4}{|l|}{ 1. The death pronouncement } \\
\hline Primary doctor & $265(61)$ & $115(43)$ & $88(33)$ \\
\hline Not primary but familiar doctor & $65(15)$ & $30(46)$ & $37(57)$ \\
\hline Not primary and unknown doctor & $86(20)$ & $41(48)$ & $52(60)$ \\
\hline \multicolumn{4}{|c|}{ 2. The attendance by doctor at the moment of patient's death } \\
\hline Attendance & $85(20)$ & $37(44)$ & $25(29)$ \\
\hline No attendance with frequent visit on that day & $119(27)$ & $53(45)$ & $45(38)$ \\
\hline No attendance with rare visit on that day & $204(47)$ & $96(47)$ & $106(52)$ \\
\hline \multicolumn{4}{|c|}{ 3. The attendance by a nurse at the moment of patient's death } \\
\hline Attendance & $178(41)$ & $88(49)$ & $67(38)$ \\
\hline No attendance with frequent visit on that day & $168(38)$ & $69(41)$ & $69(41)$ \\
\hline No attendance with rare visit on that day & $65(15)$ & $28(43)$ & $40(62)$ \\
\hline \multicolumn{4}{|l|}{ 4. Continuous monitoring with an electrocardiogram } \\
\hline Not monitored & $318(73)$ & $142(45)$ & $142(45)$ \\
\hline Monitored without the equipment in the room & $42(10)$ & $20(48)$ & $18(43)$ \\
\hline Monitored with the equipment in the room & $36(8.2)$ & $18(50)$ & $14(39)$ \\
\hline
\end{tabular}

Some of the data does not add up to $100 \%$ due to missing data.

*A high level of perceived emotional distress by a family was defined as 'very distressed'.

** High level of necessity for improvement was defined as by families as 'some improvement was needed', 'much improvement was needed', and 'considerable improvement was needed'. 
Table 3. Comparison of the level of family-perceived the need for improvement in the care of a dying patient

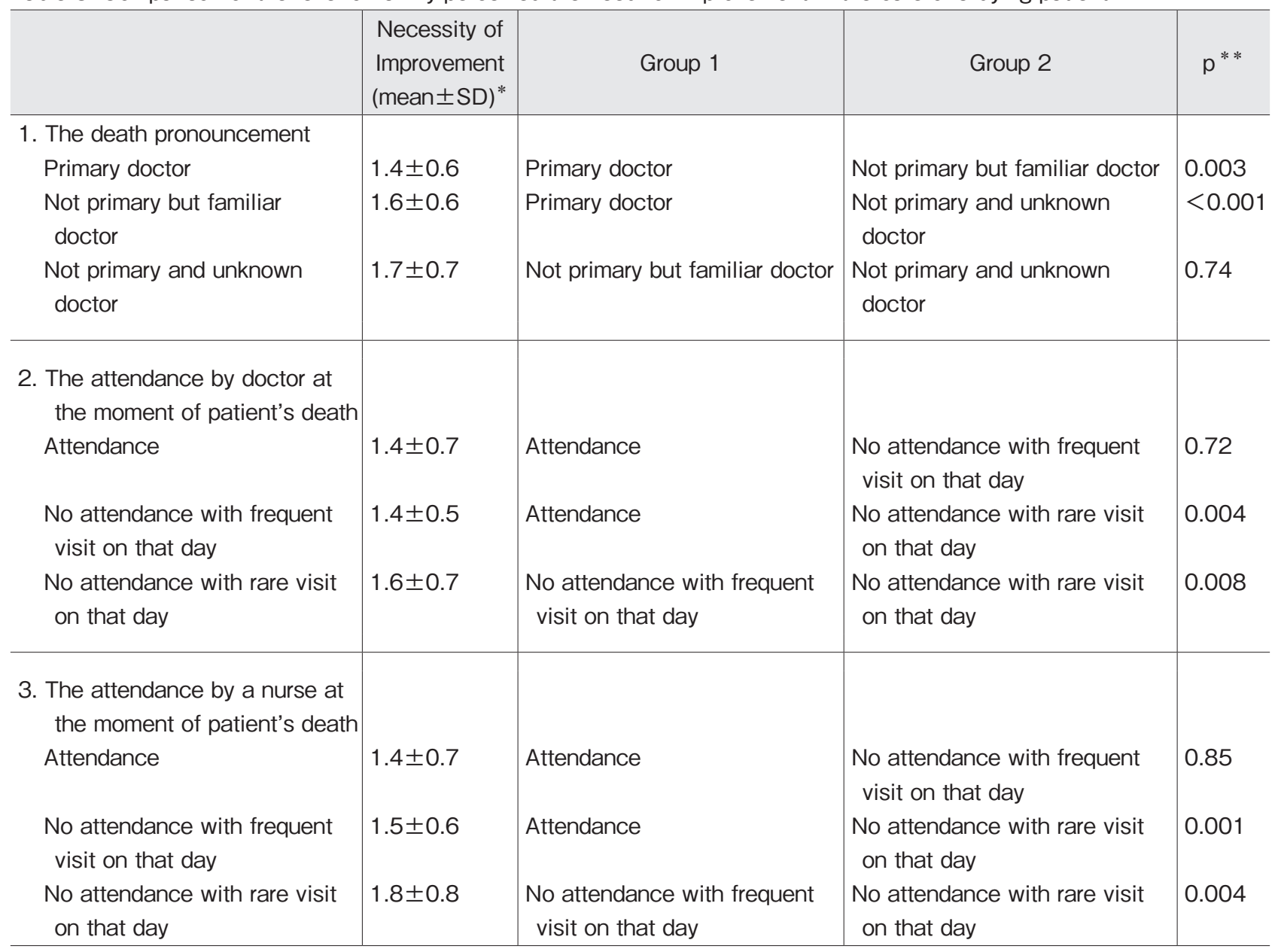

* The level of family-perceived need for improvements in care was evaluated with a four-point scale; 1: no improvement was needed-4: much improvement was needed

** The Steel-Dwass multiple comparison method 